\title{
Juxtaglomerular Apparatus
}

National Cancer Institute

\section{Source}

National Cancer Institute. Juxtaglomerular Apparatus. NCI Thesaurus. Code C32891.

Cellular population adjacent to the renal corpuscle, composed of the macula densa, the juxtag lomerular cells, and the extraglomerular mesangial cells. It regulates the blood pressure by activating the renin-angiotensin-aldosterone system. 